\title{
Socialism
}

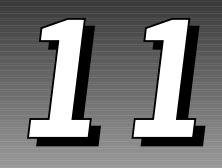

Here we explore socialism - an ideology that, uniquely, sprang from the industrial revolution and the experience of the class that was its product, the working class. Though a more coherent ideology than conservatism, socialism has several markedly different strands. In order to appreciate these, and the roots of socialism in a concrete historical experience, we explore its origins and development in the last two centuries in some depth, giving particular attention to the British Labour Party. We conclude with some reflections on 'Blairism' and the 'Third Way', and the possible future of socialism as an ideology.

\section{POINTS TO CONSIDER}

Does the assertion that socialism is the product of specific historical circumstances cast doubt on its claims to universal validity?

> Is utopian socialism mere daydreaming?

- Which is the more important of socialism's claims: justice or efficiency?

> Does common ownership equate with state ownership?

Do socialists mean more by equality than liberals do?

- Is socialism in Britain simply what the Labour Party does?

- Is there a future for socialism? 
The general diffusion of manufacturers throughout a country generates a new character in its inhabitants; and as this character is formed upon a principle quite unfavourable to individual or general happiness, it will produce the most lamentable and permanent evils, unless the tendency be counteracted by legislative interference and direction. (Robert Owen, Observations on the Effects of the Manufacturing System, 1815)

(T)he difference is that the enemy is more subtle and stealthy than before. Capitalism remains the oppressor it has always been, but the inequality and humiliation which used to stare out at you at every street corner is now harder to see, even possible to miss altogether. (A delegate at the Labour Party Annual Conference, 1973)

Like liberalism and conservatism, socialism was a nineteenth-century development with its roots in the eighteenth century and even earlier. It grew up with industrialisation and urbanisation, a process that was under way in Britain by the 1750s and spread to Western Europe during the early part of the 1800s. This process created the modern factory system (which is only now beginning to disappear in the industrialised West) and generated new industrial and manufacturing classes and elites, and, most important for socialism, the modern industrial working class. Out of this working class arose trade unions, building societies, co-operatives, all influenced by socialism, the ideology of the working classes.

Any political movement or ideology requires a group in society to which it can appeal. Socialism without industrialisation, without a working

industrialisation

The process of developing increased output of

manufactured goods by the application of technology and capital resources. It involves a massive reform of all social, economic, cultural and ideological structures in society. class, was essentially a utopian or idealistic movement. Without a collectivist or class doctrine it would have essentially been an ideological wing of radical liberalism. To reiterate: it was nineteenth-century capitalist industrialisation that created the working class and socialism.

From its very beginnings socialism was a many-faceted ideology, one that can be roughly divided into four main types, all of which have been influenced by idealist or 'utopian' socialism:

- social reformism or social democracy;

- Marxism or Marxism-Leninism;

- anarchism;

- Third World socialism.

All these movements would call themselves 'socialist'; all criticise liberal capitalism; all desire social change to improve the lot of the mass of the population. However, they are often involved in bitter ideological argument with each other. Socialism is the most self-consciously ideological of the major 
political movements. Theory and ideas are essential to an analysis of capitalist society and how it might be replaced or at least reformed. As a consequence it has a tendency to fragment into competing ideological groups, each claiming the 'truth', each based on the 'correct' interpretations of key texts.

The experience of these socialist strains in changing society is varied. In most Western societies socialism or social reformism has rarely held political power for long. However, it has greatly influenced Western European political culture and may be considered a major element of the dominant ideologies in those societies, as it is closely associated with welfare states, Keynesian economic management and a culture of social and political rights. While it constitutes a class analysis of society social reformism offers high levels of personal freedom aided by state action and state institutions.

Socialism of the Marxist strain was connected with the communist states of Eastern Europe, the USSR and the People's Republic of China (PRC). It stressed egalitarian values more than individual freedom. State power was used to strengthen these values as a stage towards the achievement of communism. All too often state socialism tended to stress the 'state', rather than 'socialism', and oppressed the working classes more than the capitalism it replaced. The opponents of social democracy in the West tended to envisage Marxist socialism as the kind that social-democratic parties were planning to introduce.

Anarchism is confined to the fringes of politics and socialist movements. It is dismissed as largely an irrelevance in complex Western societies, confined to 'eccentrics', 'drop outs', and the like. However, it offers an often-powerful critique of state power.

Third World socialist states have attempted to create a form of socialism without a working class or the industrialism that goes with it. Such states have usually become associated with poverty, backwardness and failure. There is a strong current of nationalism and anti-colonialism in this form of socialism.

We concentrate here on social reformism, also known as 'revisionist socialism', 'social democracy' and 'democratic socialism'. In particular, we look at the British version of socialism in the form of the Labour Party. Marxist and anarchist contributions to socialism will be discussed in Chapter 12. Third World socialism is usually a variation of one of the three other versions adapted, with varying degrees of commitment and success, to non-industrialised societies.

\section{Defining socialism}

Perhaps more than most political philosophies, socialism resists easy definitione, chiefly because of the wide range of theorists, writers and activists who 
have claimed (or have been accorded) the title 'socialist'. Confusion has been compounded by the eagerness with which many 'socialists' have denounced the beliefs and actions of other 'socialists' as a betrayal of the faith.

It could, however, be argued that there are at least two fundamental points on which all socialists agree, and which distinguish all the many varieties of socialism from other ideologies. First is their attitude to property. For socialists the structure of property ownership in a capitalist society at any given time is radically unsatisfactory. Property, at least productive property rather than personal possessions, should be redistributed, not to individuals but rather to some form of communal or collective ownership.

The second feature is that socialism offers a class analysis of society arising out of the relationships between social groups as a consequence of the unequal distribution of property ownership. Financial inequality and the unequal opportunities open to people as a consequence of their position in the capitalist class structure are seen as fundamentally unjust and should be reformed in favour of greater social equality.

Admittedly, even this definition does not entirely suffice to cover the extensive rethinking of socialism in very recent times, but it forms a useful starting point.

\section{Divisions within socialism}

From the outset there were major divisions within socialism. One obvious source of division concerned the end product: what sort of society ought to replace the existing system? While this might seem an obvious question, in fact the main dispute within socialism, the basic faultline, was the issue of how a new society might be brought about.

\section{Utopian and revolutionary socialism}

Early nineteenth-century socialists may be divided into 'utopian' and 'revolutionary' socialists.

Utopians believed that moral argument, reason and action within the existing order constituted the way forward. They spoke in the name of reason and natural rights, but they still had a mystical belief in change. Hence, for example, the visionary schemes of Charles Fourier in France, who argued for the creation of associations and planned co-operatives; and as another instance, the founding of 'communes' by Robert Owen in Britain and America as an alternative to capitalist systems of production and ways of living.

Revolutionary socialists, such as Karl Marx, dismissed these schemes as pipe dreams. Only the violent overthrow of the state, the tool of the capitalist class to oppress the workers, would make possible the creation of a socialist society. 
While revolutionary attitudes dominated the middle part of the nineteenth century the slow evolution of at least a degree of democracy through the extension of the franchise, and slow but steadily rising living standards for the workers, led to the emergence of 'revisionism'.

\section{Revisionist and revolutionary socialism}

The revisionist view of socialism was that the state was more or less neutral and that socialists could gain control of it by peaceful, constitutional means by contesting elections and ultimately being voted into power. Once in government they would enact socialism via the normal legal processes. These ideas developed out of the German Social Democratic Party from the middle of the century.

An important figure here was Eduard Bernstein, who joined the SDP in 1872 and soon became one of its leading journalists. In Evolutionary Socialism (1898) he argued for reform through parliamentary action, rather than by revolution, as the basis for a socialist party. He believed that Marx's predictions of revolution were simply wrong. Working-class movements, such as trade unions, offered a means to achieve real gains for workers without revolution or some form of 'proletarian dictatorship'. Despite Bismarck's anti-socialist laws the SDP's vote continued to grow, thus showing that a democratic means to socialism had developed. Revolution was redundant.

The socialist Second International (1889-1914) was dominated by rows between supporters of revolutionary and revisionist roads to socialism. Marx and Engels opposed Bernstein's revisionist views of socialism and called for his resignation from the SDP and the Second International. They disliked intensely his claims that Marxism was irrelevant and a nuisance to socialist development. To revolutionary socialists revisionism - or 'reformism' - failed to grasp the essentially exploitative nature of capitalism and the capitalist state. They believed that capitalism could not be reformed. At best it would only make sufficient concessions to ensure the continuation of capitalist power.

While during the nineteenth and much of the twentieth century the main conflicts were over alternative 'roads to socialism', by the late twentieth century socialists were increasingly questioning what the ultimate destination should be. Revisionism, first applied to the means of gaining power, was now applied to what should be done with that power once it was achieved.

\section{Continental and British socialism}

Socialists have historically been anxious to stress the international nature of the movement and the universal applicability of its principles. In fact, though, the various strands of socialist thought have been powerfully influenced by 
the historical and cultural setting in which they developed. Continental socialism evolved in a markedly different context from that of British socialism. Of particular significance were the powerful traditions of despotism, revolution and anti-clericalism in many European countries. British socialism, by contrast, had its own indigenous roots, its own political and economic environment

anti-clericalism

A feature of most leftist politics in Catholic European countries. Anti-clericalism claims that the Roman Catholic Church has too much say in politics and its role should be resisted and, eventually, eliminated.

and its own distinctive qualities. Of major importance were the traditions of constitutional government and political continuity.

British socialism has rejected Marxism as a major trend. It has been greatly influenced by revisionism and the Fabian movement of Sydney and Beatrice Webb, who regarded Owen as the founder of British socialism and preached human brotherhood rather than class war. A class analysis is certainly part of British socialism but class war is regarded as irrelevant to the solving of practical social problems. Indeed, parliamentary roads to socialism can be more effective than revolutionary means. British socialism has always considered, for example, the European socialist stress on the political general strike or activity outside the lawful political system to be illegitimate and actually counter-productive.

The close links between the Labour Party and the trade unions have undermined the role of extra-parliamentary movements for socialism. Only in recent years, under New Labour, have these links been weakened.

The Labour Party as the dominant form of socialism in Britain has close cultural links with the natural conservatism and moderate values of British society. Early nineteenth-century near-revolutionary conditions abated with mid-nineteenth-century prosperity. Marx, who believed the Chartist campaign for parliamentary reform had the potential for a mass revolutionary movement in the 1830s and 1840s, eventually came to see little potential for revolution in Britain. He once famously described Britain as having 'a bourgeois aristocracy, a bourgeois middle class and a bourgeois working class'. The Labour Party steadily emerged as the major anti-Conservative party during the 1920 s and 1930s. The 'safe' nature of the Labour Party was underlined by two short periods in government and, especially, by its role as a partner in the National Government during the Second World War. No charges of unpatriotic 'shirking' could be made against it when it came to power in 1945.

\section{Chartism}

A mass working-class movement for political reform in Britain during the 1830s and 1840 s. It called for six reforms, among which were universal adult male suffrage, annual parliaments and wages for MPs. 


\section{Scientific and romantic socialism}

Another tension within the socialist tradition might be identified as that between 'scientific' and 'romantic' socialism.

Scientific socialism harks back to the Enlightenment, the idea of human perfectibility and the application of human reason to the understanding and appropriate modification of human society. For this school, socialism was right because it was more rational and more efficient a means of organising society than the free market. A variant of this approach was that of the later writings of Karl Marx, where he claimed that the ultimate triumph of socialism was built into laws governing the development of human society. These laws could be uncovered by the application of scientific method and once discovered could be applied to improving society, 'nudging' historical events along to bring inevitable change forward.

Romantic socialists based their approach on a moral vision of humanity. The existing capitalist order crushed the human spirit, blighted creativity, caused poverty, misery, degradation and crime. It was deemed a fundamentally unjust system, based on selfishness, cruelty, exploitation and greed. These evils could and should be removed or mitigated. Romantic socialism, therefore, was essentially moral, its inspiration revolutionary and its appeal emotional.

\section{Socialist themes}

There are, in addition to the common views of socialists already identified, a number of major themes around which socialists build their creed, even if they do not agree on the relative importance or priority of their realisation:

- an optimistic view of human nature;

- a belief in some form of common ownership;

- a commitment to equality;

- freedom as a goal of socialism;

- socialism and the state.

\section{An optimistic view of human nature}

Socialists of all persuasions have generally held an optimistic view of human nature. They themselves would call it realistic. Most people have a natural desire to help others, to be part of a common project, to be valued members of society. Man is perfectible by his own efforts. A good society is possible. Such a society will come about by greatly modifying the existing capitalist society or replacing it with one based on socialist values, however they might be defined.

The evils of war, crime, ignorance, unemployment, poverty and even disease are regarded as largely the product of capitalist economic and social arrangements. 
Remove these and all would be improved. Scientific socialists can, in this sense, be regarded as heirs to the Enlightenment tradition. Romantic socialists, with their preoccupation with the soul of man, may have had a post-Enlightenment starting point but their conclusions were much the same.

Such a socialist vision has a strong ethical component, even when, in the case of scientific socialism, it purports to be based on scientifically proven fact. This moral drive comes from a belief in the essentially social nature of humanity. As we attain our 'true' humanity through social interaction, and this interaction occurs in a specific context, it is crucial that the structures in which the interaction takes place be designed to maximise human cooperation and community. Given the appropriate structures, man's instinct to co-operate will flourish and the individual will achieve his full potential. Cooperation, therefore, rather than competition, is the hallmark of a socialist society. This applies with particular force to economic competition.

\section{A belief in some form of common ownership}

Since co-operation is essential to human well-being, and humans are naturally co-operative, social animals, it follows that economic co-operation is crucial. Socialists criticise capitalism and the institution of private property for promoting conflict rather than co-operation. Moreover, the private ownership of productive wealth is unjust since the owner of such wealth derives personal profit from the product of the community's work.

Classical socialists, therefore, argue that private ownership be replaced by collective ownership. More moderate or revisionist socialists propose various means by which private ownership should be subject to the common good. These involve either state ownership of certain key industries on behalf of the whole people, or some form of worker joint ownership, or joint ownership by means of a co-operative community working together to earn a living and raise children.

\section{A commitment to equality}

It might seem from the above that socialists are committed to full equality, or egalitarianism, as one might define it. In a sense they are, but this commitment is often misrepresented. Only the most extreme versions of socialism propose that everyone should have exactly the same amount of material wealth. Most socialists assume some variations in wealth among people and, in practice, are inclined to favour less inequality rather than mathematically exact equality.

While they share with liberals a belief in the equal value of human beings (who should all be accorded equal rights and consideration), socialists 
attribute most inequality not to differences in inherent talent, effort or responsibility, but to social factors, such as access to education, wealth and social class. Thus unequal outcomes in education or health are due to inequalities in starting points. Such unequal outcomes are both unjust and inefficient, since much human capital is thereby squandered. Moreover, only in a society founded on equality can the liberal goal of liberty be achieved.

As private property is the root cause of social inequality, socialists say that it must be tackled as an issue. Revolutionary socialists see a need to control most private property for the public good and social improvement. Revisionist socialists, on the other hand, seek not the abolition of private property but the application of measures, most notably by the tax system and public spending, to redistribute wealth in society along more equitable lines.

\section{Freedom as a goal of socialism}

Liberals defend the freedom of the individual to pursue his or her own interests, trusting in the 'hidden hand' for the overall amelioration of society. Socialists, however, believe that the deep inequality and poverty created by capitalism mean that society cannot be free until the economic system is transformed. To them such a society will have a 'hidden elbow' as the poor, the weak and the working classes are pushed to one side. Their freedom will be infringed, if not removed altogether, by untrammelled capitalism and the minimal state.

Hence, to ensure increased real freedom for the majority of the people, the freedom of the few may need to be curbed and institutions set in place to help people realise their potential as individuals. This may involve the outright removal of capitalism or its reform, including state-provided education, health services and benefit systems.

\section{Socialism and the state}

It is a widespread misconception that socialism's commitment to the collective ownership of property equates with state ownership, and that the state therefore plays a very positive role in socialist thinking. In fact, there have historically been many attitudes towards the state within the socialist tradition. The equation of state ownership and collectivism was dominant only from the late nineteenth to the late twentieth century and even then it was never complete. For example, many early twentieth-century British socialists thought nationalisation would just replace oppressive private capitalists with

nationalisation

The taking into state ownership of major industries to be managed for the public good rather than private profit. In Britain during the late 1940 s this involved the nationalisation of the coal, steel, railway, water, electricity and gas industries. 
even more powerful oppressive state employers. Indeed, it could be argued that in the twenty-first century Western social democrats are moving away from state ownership as rapidly as conservatives are. Nevertheless, it is true that some versions of socialism present state ownership as the absolute and defining truth, denouncing all deviation from this as a gross betrayal of fundamentals.

Broadly speaking, socialists have held three contrasting attitudes to the state. One is that the state is essentially irrelevant. The people, especially the working class, must construct socialism. Another view is that the state is an enemy, the tool of the oppressing classes that must be smashed by force for any real socialist advance to be made. Thirdly, there is the belief that the state can be captured and turned to the positive benefit of the people.

During the early nineteenth century, prior to the existence of states with universal suffrage and respect for civil rights, and when the working class was but a small minority of the population, revolutionary socialism aiming at the overthrow of the state predominated. The dismal failure of revolutionary action throughout Europe during 1848-9, the widening of the franchise and extensive social reform in countries such as Britain, even state provision of welfare benefits like pensions as in Germany, led many socialists to a fundamental reappraisal of the role of the state. Some, such as Bernstein in Germany and the Fabians in Britain, concluded that the state could be adapted to a very positive role if socialist parties acquired power by constitutional means.

This belief reached its apogee in Britain during and just after the Second World War. State planning helped to defeat Britain's enemies and could, it was believed, win the war against ignorance, poverty and want at home. Social reformism was the dominant ideology throughout most of the post-war era. Recently, though, socialist thought in Britain and in the Western world has lost confidence in state ownership as a panacea.

\section{The early history of socialism}

Although most critics have argued that the term 'socialist' can be applied only to critiques of capitalist society, some have seen the genesis of socialism in Plato and even Moses. Others have seen radical socialism in the declarations made by the leaders of peasant revolts in England in the 1380s or Germany in the 1520s. There may even be a plausible case for the origins of British socialism to be found in Thomas More's Utopia (1516) or in the activities of Gerrard Winstanley and the Diggers in the mid-seventeenth century. For our purposes, however, modern socialism can be said to have originated in the early nineteenth century as a response to two major historical events, the French Revolution (1789) and the industrial revolution from the mid-eighteenth century onwards. 
The French Revolution overturned the existing political order and thrust such concepts as the rights of man and values such as equality and fraternity to the forefront of political discourse. Such was the perceived threat to the established order from British radicalism that it was ruthlessly suppressed by the authorities during and after the Revolutionary and Napoleonic Wars (1792-1815). However, radical ideas remained to fertilise the development of socialism in Britain.

The industrial revolution produced, as we have observed, new economic and social structures - a new class system - based on capitalism. These structures nullified in practice the values espoused by the French Revolution. Industrialisation was characterised by injustice, inequality, suffering and degradation for the vast majority of the population. It was this state of affairs that early socialists tried to confront and turn to good.

\section{Socialism before the Labour Party}

We have already seen some ways in which British socialism differs from its European counterparts. We will now study its development in somewhat more detail.

\section{Utopian socialism}

Utopian socialism (so-called by Marx to distinguish it from his own scientific socialism) emerged in the backwash of the French Revolutionary and Napoleonic Wars and the steady spread of the industrial revolution in Europe. In continental Europe the most notable figures were Charles Fourier and his schemes for new associations, and Claude, Comte de Saint-Simon, who believed industrialisation could be harnessed by engineers and technicians to modernise society for the benefit of all.

In Britain it was Robert Owen who played a crucial role. Owen's socialist career began with his development of the New Lanark cotton mill in Scotland into a model factory and community (after 1800). He believed that people could be changed if society was changed. Owen subsequently developed ideas for other ideal communities based on the co-operative principle and when these received little support in Britain he set one up at New Harmony in America (1824-29). Later in Britain he promoted a wide range of organisations, such as trade unions, co-operative societies and friendly societies. Crucially, Owen's socialism depended not on the state but on voluntary action. Most of these initiatives proved stillborn and, apart from the Christian Socialists, who urged moral revival rather than institutional reform, the utopian socialist movement in Britain faded. The nascent tradeunion movement, which Owen once thought would play an important role 
in socialist development, concentrated on improving working conditions within the existing capitalist framework, rather than on changing the whole of society.

\section{British Marxism and William Morris}

Marx spent much of his time in England. His ideas were largely based on an analysis of the capitalist system in England and he borrowed many of his concepts from British economists, such as Adam Smith and David Ricardo. However, Marx's ideas had little impact in Britain until the worsening economic circumstances of the 1880s led to the creation by the wealthy eccentric H. M. Hyndman of the Social Democratic Federation (1884), a tiny and unorthodox Marxist faction which came to nothing.

A more significant figure was William Morris, who was much influenced by the art critic John Ruskin. Ruskin argued that the 'bad' art which he thought characteristic of the nineteenth century was the product of a bad society. Morris, himself an artist, craftsman and poet, further refined these notions, believing that all human beings were essentially creative. The exploitative capitalist system and its associated industrial production methods stifled this creative urge. Originally a member of Hyndman's SDF, Morris soon left to found the Socialist League (1884). In his extensive writings, such as News from Nowhere (1891), Morris tried to propagate his beliefs, though without any discernible impact on the politics of the day.

\section{Ethical socialism}

Another tributary flowing into the broader current of British socialism was 'ethical socialism'. In part derived from an interpretation of Christianity, in part a quasi-religion in its own right, ethical socialism had considerable influence on the New Trade Unionism, which was developing in the 1890s, and subsequently on the Labour Party, founded in 1900. Important figures were the pioneer Labour leader, Keir Hardie, and Robert Blatchford and John Bruce-Glasier. Although ethical socialism had little intellectual content it nevertheless combined romantic socialism with Fabian gradualness and legality.

Ethical socialism stressed a strong commitment to social justice and the better distribution of economic and other rewards in society - to reduce inequality, not actually to create equality. There is little here about abolishing capitalism, only reforming it. Justice and freedom are as important in this strain of British socialism as in any other. Indeed, British socialism derives its inspiration from some of the New Liberal thinkers of the late nineteenth and early twentieth centuries, while shading into Fabian socialism. 


\section{Fabianism}

Perhaps the most distinctively British contribution to socialist thought was that of the Fabians. The Fabians took their name from the Roman general Fabius Maximus Cunctator who fought Hannibal with what today would be described as guerrilla tactics. Founded in 1884, the Fabian Society was essentially a group of intellectuals with a keen interest in social reform.

Sidney and Beatrice Webb, Graham Wallas and George Bernard Shaw elaborated Fabian ideas. They argued that there was an identity in class interest between the middle classes and the working classes, both of which were exploited by the few 'idle rich' who lived off the rent on land or capital. Moreover, socialism was seen to be emerging as a reality, with the steady advance of collectivist institutions, notably local government bodies. Socialism would be advanced not by the setting up of a socialist party, still less a working-class socialist party, but by permeating society in general with socialist arguments founded on irrefutable, factual and, especially, statistical evidence. The Fabians envisaged that in a future socialist society a major role would be played by an enlightened, uncorrupted and highly efficient civil service. The Fabians could claim to be the 'wave of the future', as such a civil service was already emerging. Simultaneously, even the Liberal Party was moving towards state

pacifism

The belief that violence in any cause is morally wrong and should not be resorted to in order to pursue political goals in domestic or foreign policy. Pacifism is particularly associated with religious movements such as the Quakers. provision of pensions, while local authorities were increasingly providing utilities like gas and electricity, public transport, and amenities like parks, swimming baths and libraries.

\section{The Labour Party: a very British socialism}

Utopian socialism, Marxism, nonconformist Christianity, class struggle, trade unionism, Fabianism, vegetarianism, pacifism and New Liberalism all contributed to the development of British socialism in the form of the Labour Party. The Labour Party is one of the least ideological socialist parties in Europe but, arguably, one that has changed its society the most.

\section{The formation of the Labour Party}

The formation of the Labour Representation Committee in 1900 led to the creation of the Labour Party in 1901, which was to prove of the utmost importance for the development of British socialism. Its initial inspiration was not, however, socialism but 'labourism' - that is, the promotion of the interests of the working class, especially the male, skilled working class, by vigorous trade-union action. 
Although the trade unions were developing rapidly at the end of the nineteenth century, with the emergence of large unions composed of unskilled workers, they were badly hit by an adverse court decision in the Taff Vale Case (1901). A railway company sued a union for damages caused to its business when its employees went on strike. The court's decision in favour of the company undermined the entire legal basis on which trade unionism had operated for decades, so the unions were anxious for legislation to redefine their legal position. Moreover, while the unions had tended to support the Liberal Party, even sponsoring some Liberal parliamentary candidates in working-class areas, the intellectual baggage and social composition of the Liberal Party were not unambiguously on the side of the unions.

The initial aim of the Labour Party was to secure the return of working-class and trade-union men to the House of Commons. The party's name and its complex structure, which incorporated trade unions and socialist societies, like the Fabians, clearly proclaimed its identity.

Before the First World War the Labour Party enjoyed some electoral success by 1914 it had forty-two MPs. By 1918 the situation had been transformed. The Liberals had split in 1916 over the formation of a wartime coalition government with the Conservatives. In 1918 the franchise had been extended to include most men and women. Finally, the party adopted a new constitution whose famous Clause IV committed it:

To secure for the worker by hand or brain the full fruits of their industry and the most equitable distribution thereof that may be possible upon the basis of common ownership of the means of production, distribution and exchange and the best obtainable system of popular administration and control of each industry or service.

This could only mean socialism, but the exact form of socialism remained unclear.

\section{Labour in office: the 1920s and 1930s}

Labour came to office in 1924 and again in 192931 . In both cases it was a minority government. The first term, on the face of it, achieved nothing. The second ended in apparent disaster when Labour Party leader Ramsay Macdonald split the party by joining a coalition government dominated by the Conservatives in response to the world economic coalition government A government made up of two or more different political parties or groups. The National governments of 1931-35 and 1940-45 were coalition governments. slump and financial crisis.

These two periods of office were, however, not as futile as might first appear. Under Macdonald the party established that it had the capacity to govern, moved further away from Marxism, and decisively committed itself to the 'parliamentary road' to socialism, especially after the abortive General Strike (1926). 
Intellectually, there was considerable activity. 'Syndicalism', the doctrine that the working class could and should seize power by a 'general strike' prompted by the unions, was increasingly attractive as an industrial road to socialism. Syndicalism had been popular on the fringes of the movement but was decisively rejected.

Ramsay Macdonald made some contribution to socialist thought, arguing, for example, in The Socialist Movement (1911), that socialism was in a sense a conservative creed in that it aimed at moving society back to its natural path of evolutionary social integration, a path temporarily blocked by capitalism.

G. D. H. Cole advocated 'guild socialism', in which each individual industry would be run by the workers in a co-operative system, the whole being coordinated by the state. In Guild Socialism Restated (1920) Cole helped guild socialism to become a major element in socialist theory in the early twentieth century. He believed that it would strengthen democracy and resist the capitalist treatment of workers as a commodity.

The most significant thinker, however, was R. H. Tawney. Tawney based his socialism on Christian ethics. In The Acquisitive Society (1921) and Equality (1931), as well as in many public lectures, he emphasised community, cooperation, service, duties - rather than rights - in a way that has interesting echoes in attitudes displayed by Tony Blair in recent years.

Nevertheless, advocates were still to be heard for the radical transformation of society, one of the most important of whom was Harold Laski. In Democracy in Crisis (1933) Laski argued that capitalism still controlled the state and would prevent the realisation of democracy and socialism unless a radical Labour Government used whatever methods were necessary to overcome capitalist resistance and to introduce socialism. Such methods might include emergency powers and a radical departure from traditional constitutional means.

\section{Labour in power: $1945-51$}

In 1945 Labour swept to power with an unprecedented majority. It was in a position for the first time to embark on a genuinely democratic socialist programme. Events during the war had had a profound influence on Labour. Labour was part of the wartime coalition government. Its leader, Clement Attlee, was deputy prime minister. Other senior Labour figures held important Cabinet posts and dealt with real and pressing problems, demonstrating judgement and competence.

The war effort had involved state control and planning on a huge scale, establishing a general consensus that state wartime planning could successfully be applied to peacetime problems. Once more, the general sense of optimism and of 'no turning back' to the evils of the twenties and thirties boosted Labour's 
confidence. Already before the war, the National Government had introduced a number of welfare reforms, which culminated in the Beveridge Report (1942) on which Labour based its 'welfare state', a 'cradle to grave' protection of the citizen by the state. Keynesian theories of Demand Management to regulate levels of employment in the economy were now part of the conventional wisdom of both government and governed.

The government was also determined to 'nationalise' major industries and utilities. These would be organised into state-owned public corporations, run in the 'national interest' as a hard-headed, practical form of socialism, as distinct from the unrealistic dreams of syndicalists and guild socialists.

In many ways the government was extraordinarily successful. Unemployment did not recur, as it had after the First World War. A National Health Service was established. Major industries, coal, steel, shipbuilding and railways, were taken into public ownership. A host of social reforms accompanied these remarkable achievements, all accomplished in spite of the material and financial devastation created by war and the perceived threat from Soviet communism.

Paradoxically, though, Labour's style of socialism was beginning to decline in the moment of its apparent triumph. Planning proved inefficient, over-bureaucratic and less appropriate for the goals of peace than it had been in wartime. Added to the acute economic problems of the post-war world were rationing, shortages and a general feeling of overbearing officialdom. Nationalisation became less and less popular, even among workers in the state corporations, and the welfare state became steadily more expensive, with the bulk of the tax burden to pay for it resting on working-class people.

By 1951 Labour was widely perceived as an exhausted government. Many of its ministers had been in government for ten years through war and post-war reconstruction. Nevertheless, the Conservatives only just won the election. They were to stay in power for thirteen years.

\section{Labour in opposition and in government: 1951-79}

During these years Labour was riven by tensions between the 'democratic socialists' who wanted to press on along the road Labour had taken in 1945, and the 'social democrats' who hoped Labour's goals might be achieved by another route. This was no mere intellectual debate. At all points, electoral considerations were fundamental.

Anthony Crosland made an important contribution to the debate. In The Future of Socialism (1956) his revisionist thesis stressed that the essence of socialism was the ends not the means. Crosland argued that capitalism had changed radically. Ownership was irrelevant since the typical business enterprise was now a corporation run by managers concerned with the 
long-term success of the company. Owners were essentially passive shareholders. Such firms were a positive benefit to socialism. Their profits were ploughed back into businesses, improving efficiency and raising living standards. Full employment would eliminate the exploitation of the workforce since workers could choose whom to work for and competition would eliminate the exploitation of consumers. Such wealth-producing enterprises could contribute to social improvement by making possible the provision of welfare benefits and the reduction of inequality by redistribution and progressive taxation.

These ideas had a seismic impact on the Labour Party. The right-wing 'social democrats' seized on them enthusiastically, while the left wing rejected them. Rows over the direction for the Labour Party were to contribute to Labour's successive electoral defeats in the 1950s.

In spite of these tensions Labour was returned to power in 1964 (and again in 1966) under Harold Wilson. Intellectually, these proved sterile years. Wilson and several Labour leaders were later to produce memoirs, diaries and analyses of their Labour Government, although they rarely discussed the nature of British socialism. Indeed, many Labour supporters were deeply disillusioned by Labour's failures to manage the economy successfully or extend socialism in society.

Labour returned to power in 1974 with a considerably more left-wing agenda, but with very little in the way of a mandate from the voters to carry it out and almost no commitment to it by the Labour leadership. It did increase welfare spending and take over some failing industries, notably British Leyland in 1975, but it was soon overwhelmed by the world economic recession that gathered pace after 1973. Inflation and unemployment rose. The Labour Government cut public spending; social conflicts, especially strikes, multiplied. The social-democratic approach appeared bankrupt. Keynesian economic management techniques no longer worked and the inherent conflict between high taxation (for welfare and wealth redistribution) and economic efficiency became clearly evident.

\section{Labour in opposition again: 1979-97}

After losing power to the Conservatives in 1979 Labour had once again to face internal sectional conflicts. The result was the defection of a substantial part of the right wing of the party to the newly formed Social Democrats in 1981; and on the left there was a revival of 'classical socialism', tinged with Marxism. The ideological civil war in the Labour Party, which was to contribute to its being out of power for eighteen years, was exacerbated by rows over nuclear disarmament and Europe. 
The re-emergence of classical socialism was already under way during the 1970s. It became closely identified with Tony Benn, who campaigned energetically for it in the Labour Party. Benn's ideas were propounded in Arguments for Socialism (1980) and Arguments for Democracy (1981). For Benn, socialism and democracy were two sides of the same coin. He argued for full-blooded Clause IV socialism, a radical foreign and defence policy, wealth distribution and democratisation, especially of the Labour Party itself. This last was implemented in the new arrangements for the election of the leader in 1981. The Labour manifesto for the 1983 general election was so radically socialist that one senior Labour politician described it as 'the longest suicide note in history'.

After the crushing defeat that followed, the party leader, Michael Foot, resigned and was replaced by Neil Kinnock. Despite his leftist reputation, Kinnock began the process of reform by purging Militant supporters. Although the party was mindful of electoral considerations (but still defeated in 1987 and 1992) there was a strong ideological rethink under Kinnock and his immediate successor John Smith, and at an accelerated pace under Tony Blair (who became leader in 1994 on Smith's death).

Symbolic of these reforms was the abolition of Clause IV at the 1995 party conference. The new Clause IV was considerably longer than the 1918 version, and less dignified in its language. It described the Labour Party as a 'democratic socialist party', but its essence was to commit the party to:

work for a dynamic economy, serving the public interest, in which the enterprise of the market and the rigour of competition are joined with the forces of partnership and co-operation to produce the wealth the nation needs and the opportunity for all to work and prosper, with a thriving private sector and high quality public services, where those undertakings essential to the public good are either owned by the public or accountable to them.

'New Labour', as it liked to be called, had clearly moved a long way from classical socialism. The question remained, where was it moving to? Politically, New Labour was far more a party of the centre than of the left. Beyond that it was difficult to tell.

To make sense of New Labour, it needs to be set in both a global and a domestic context. On the global stage, the collapse of Soviet communism in the late 1980s and early 1990s sounded the death-knell of the command economy as a viable alternative to capitalism. The term 'globalisation' suggests that the nation-state no longer had a sufficient power base to control its own economy or even effectively to influence global economic forces. There were important consequences for all forms of state regulation, but especially taxation, interest rates, exchange rates, subsidies and, ultimately, welfare benefits. The power of international markets was clearly illustrated by Britain's forced withdrawal from the European Exchange Rate Mechanism in 
September 1992 (membership of which had been a key plank of the government's economic policy) - a policy debacle from which, politically, the Conservative Government never really recovered. Globalisation was reinforced at an institutional level by such bodies as the World Trade Organisation, the International Monetary Fund and the World Bank, all of which are designed to ensure the effective running of the global capitalist economy. Socialist parties were thus confronted by acute social problems. Most have been forced into some sort of accommodation with the global market system, dominated by the arch capitalist power, the USA.

Domestically, British society has been transformed over the last twenty years. Old industries, coal, steel, shipbuilding, heavy industry, large factories, the bedrock of Labour's traditional voting strength, have largely disappeared. As a result, the power of trade unions has declined, especially after they suffered a number of spectacular defeats during the early 1980s at the hands of the Thatcher Government. New industries arose, especially in new technology areas and the service sector, with little unionisation and very little sense of class solidarity among the workers. Indeed, the class system was radically altered and with it the nation's voting patterns. Most of the population could be described as 'middle class' by the 1990s. Property ownership had grown: houses, cars, shares, private pensions were all more widespread than previously. Voters increasingly perceived their lives in personal terms, rather than as members of a group. Individual choice, responsibility and advancement became the prevailing aspirations of a majority of the population. An appeal to simple class resentment or class solidarity would not garner the votes Labour needed to win power again.

It was these changes that Tony Blair sought to address. Perhaps the most surprising influence on him was Margaret Thatcher. She astutely exploited the changes in society that were weakening the skilled working class's traditional commitment to Labour. Labour was associated with high taxes and apparent over-generous support for the work-shy, and Mrs Thatcher persuaded enough workers to vote Conservative to win several elections. Blair admired her challenge to entrenched vested interests and encouragement of an enterprising and dynamic society. For Blair, though, Thatcherism was inadequate. There were still powerful interests to curb - hence his commitment to 'modernisation' in the face of the 'forces of conservatism', few of which seemed to be in the Conservative Party itself. Mrs Thatcher's antipathy to the state led her to under-estimate its positive economic value in promoting, for example, 'education, education, education' (Blair's three top priorities as identified during the 1997 general election). Worst of all, Thatcher had ignored the social and cultural impact of globalisation and competition and the consequent destruction of communities, families, social stability and moral values. 


\section{'Blairism' and the 'Third Way'}

Unless one accepts Herbert Morrison's definition, 'Socialism is whatever a Labour Government does', one might argue that under the leadership of Tony Blair the Labour Party has finally cut its bonds with the form of socialism established in 1918, and has become more of a social liberal party. One could claim that there is no distinctive New Labour or 'Blairite' ideology at all, merely an intellectual black hole attracting any passing fad. Is it merely 'conservatism with a human face', a 'nice' form of Thatcherism, which is electorally highly successful but intellectually and ideologically completely barren?

Alternately a more positive interpretation can be maintained. While Blair is in no way an 'old Clause IV' socialist, his 'Third Way' is genuinely based on socialist tradition and enriched by contemporary socialist thought.

Blair certainly accepts the economic and social changes of the last two decades. He even welcomes them. What he does not accept are the ethics of selfishness and greed associated with them. In this, Blair consciously reaches back to the Christian and ethical socialism of the nineteenth century, later expounded by R. H. Tawney and others. The focus is on community - the world, the nation, the local area and the family. These naturally co-operative entities should be strengthened by a sympathetic state. This 'communitarian' approach is clearly evident in Blair's rhetoric. It emphasises duties rather than rights, a 'stakeholder capitalism' in which all have an interest in a successful market economy, 'one-nation socialism', where economic efficiency is married to 'fairness', the sovereignty of the people, and the benefit of the many rather than the few.

In so far as these slogans translate into policy, there has been a number of radical measures, for example a general toughening up on tackling crime. Welfare has moved towards 'handups', rather than 'handouts'. 'Prudence' has characterised economic management, with a very cautious approach to public spending (now redefined as 'public investment'). More specifically, there has been a policy of partnership of the state with private capital in, for example, Education Action Zones and the Public-Private Partnership to finance hospital building, the London Underground and air traffic control. In 2001 there was much talk of expanding the role of 'faith communities' (churches and religious groups) in education and welfare, with state backing. At the same time the participation by the people has been enhanced by constitutional reform, especially devolution in Wales, Scotland and Northern Ireland.

The question arises, is this in any meaningful sense, other than Morrison's, 'socialism'? Certainly, there is a role for the state as regulator, enabler and deliverer of social guidance, but not as owner. Equality is proclaimed but it is the equality of the 'level playing field': that is, equality of opportunity rather 
than equality of outcome. Redistribution of wealth via the tax and welfare system has had only modest support. The emphasis has been on bettering the lot of the poor by full employment, a dynamic economy and compulsory training rather than state handouts. There has been occasional reference to the 'stakeholder' society, though this has been interpreted as to do with promoting private pension schemes rather than retaining the meaning first given to the term by Will Hutton in his book The State We're In (1995). In his view, it was not merely the shareholders who had a 'stake' in a business, but employees, customers and the wider national community. This reality, therefore, should have 'institutional recognition'.

If this is socialism, it is socialism of a highly modified variety. Critics of Blairism (who are not confined to the left of Labour) assert that this simply isn't socialism, and whatever its merits, it shouldn't pretend to be so.

Blair has spoken much of citizenship and the value of a caring and responsible community. Not surprisingly Robert Putnam, whose book Bowling Alone: The Collapse and Revival of American Community (2001), deplores the decline of community in the USA, was rewarded with a personal audience with Tony Blair.

\section{Socialism outside the Labour Party}

Labour has not always been avowedly a socialist party. Some critics have disputed its claim to the title and many more would dispute its socialist credentials today. For socialism this may be an advantage. It can be argued that socialism has been released from the constraints of its association with the Labour Party, in much the same way as the demise of the Soviet Union has liberated Marxism. For example, some, like the Socialist Philosophers Group, have tried to reconcile socialism with the market economy. Others, such as Alisdair MacIntyre and Michael Sandel, have stressed the over-arching importance of the 'public good'. The difficulty here is that such concepts might logically be aligned with the liberal or conservative tradition; or else they might be reduced to mere platitudes so anodyne that virtually no one could disagree with them.

More positively, it could be maintained that socialist ideas and values have migrated elsewhere, possibly to the Green Party and the ecology movement, or even outside conventional politics. Here, suitably modified, they may yet prove fruitful sources of intellectual and moral challenge and political action.

\section{A socialist future?}

The end of the Soviet Union and the apparent triumph of liberal capitalism appear to have marked the end of socialism as an experiment in state power and pose a major challenge to social democracy in the West. Conservatives 
have pronounced socialism discredited and capitalism vindicated, but one might reflect that such announcements are premature.

Western voters appear deeply committed to the main planks of the welfare state as they have been described over the past half-century or so. The state institutions created to deliver social-democratic priorities such as health, welfare, education and benefit payment are stubbornly popular. Opinion polls regularly show people's willingness to pay higher taxes to improve public services. Globalisation and free markets are not automatically seen as the boon to mankind that they claim to be.

According to many opinion polls in the West, voters are strongly in favour of state planning and state ownership of key services such as electricity, water, the railways, gas, and so on. Continuing of global poverty and growing inequalities at home and abroad demonstrate that all is not well in the new liberal capitalist world.

Capitalism may, once again, be dominant in the world, but there are many people willing to challenge its moral validity and efficiency. Socialism, married to other movements such as ecologism and feminism, may yet prove an effective challenge to the dominance of the market and offer a rallying call for opponents of capitalism.

\section{Summary}

Socialism is very much a product of the industrial revolution and the class to which it gave birth, the industrial working class. While socialism has many competing branches, all agree that the existing structure of property ownership is unsatisfactory. Furthermore, socialism presents a 'class analysis' of society based on property ownership. Socialism contains many divisions - the main area of dispute being how a socialist society could be achieved. Utopian socialists believed that society could be transformed by peaceful processes. Revolutionary socialists advocated the violent overthrow of the state by the working class. Revisionist socialists declared that social change was possible by working within the existing political order. The values espoused by socialists include common ownership and social equality. Human nature is regarded as moulded by social structures. Attitudes to the state vary from outright hostility to the more positive view of the revisionist school, which believed the state could be turned to good. This latter view powerfully influenced the British Labour Party, drawing on an indigenous socialist tradition. Labour held office for a number of periods during the twentieth century and broadly implemented a socialist programme. By the 1990s, and after a long period out of office, the Labour Party reinvented itself as 'New Labour' with a more centrist and less socialist programme for government. 


\section{FURTHER READING}

Berki, R. N. Modern Ideology: SOCIALISM (J. M. Dent, 1975).

Callaghan, J. Socialism in Britain since 1884 (Blackwell, 1990).

Geoghegan, V. 'Socialism', in R. Eccleshall et al., Political Ideologies:

An introduction (Routledge, 1994), pp. 91-117.

Goodwin, B. 'Socialism', in B. Goodwin, Using Political Ideas (John

Wiley and Sons, 2001), pp. 97-119.

Heywood, A. 'Socialism', in A. Heywood, Political Ideologies: An Introduction (Macmillan,

1998), pp. 103-51.

Leach, R. 'Labourism and Socialism', in R. Leach, British Political Ideologies (Philip Allan, 1991), pp. 117-49.

Lichtheim, G. A Short History of Socialism (Fontana/Collins, 1977).

Sassoon, D. One Hundred Years of Socialism (Fontana, 1997).

Vincent, A. 'Socialism', in A. Vincent, Modern Political Ideologies (Blackwell, 1996), pp.

84-113.

Wright, A. British Socialism (Longman, 1983).

Wright, A. Socialisms: Theories and Practices (Oxford University Press, 1987).

Wright, A. 'Social Democracy and Democratic Socialism', in R. Eatwell and A. Wright

(eds.), Contemporary Political Ideologies (Pinter, 1993), pp. 78-99.

\section{SAMPLE QUESTIONS}

1 In what sense is socialism uniquely a class ideology?

2 Are the differences between revolutionary and revisionist socialism greater than the factors which unite them?

3 What does it mean to say socialism is about 'equality'?

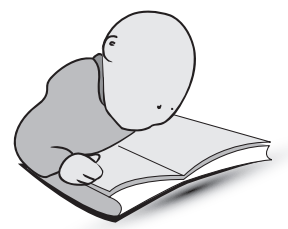

4 How socialist is 'Blairism'?

5 'Revolutionary socialism does not achieve liberty; revisionist socialism does not achieve equality.' Discuss. 